\title{
Cultural trauma, counter-narratives, and dialogical intellectuals: the works of Murakami Haruki and Mori Tatsuya in the context of the Aum affair
}

\author{
Rin Ushiyama ${ }^{1} \cdot$ Patrick Baert $^{1}$
}

Published online: 2 November 2016

(C) The Author(s) 2016. This article is published with open access at Springerlink.com

\begin{abstract}
In this article, we offer a new conceptualization of intellectuals as carriers of cultural trauma through a case study of the Aum Affair, a series of crimes and terrorist attacks committed by the Japanese new religious movement Aum Shinrikyō. In understanding the performative roles intellectuals play in trauma construction, we offer a new dichotomy between "authoritative intellectuals," who draw on their privileged parcours and status to impose a distinct trauma narrative, and "dialogical intellectuals," who engage with local actors dialogically to produce polyphonic and open-ended trauma narratives. We identify three dimensions of dialogical intellectual action: firstly, the intellectuals may be involved in dialogue with local participants; secondly, the intellectual products themselves may be dialogical in content; and thirdly, there might be a concerted effort on the part of the intellectuals to record and to disseminate dialogue between local participants. In the context of the Aum Affair, we analyze the works of Murakami Haruki and Mori Tatsuya as dialogical intellectuals while they sought, with the help of local actors' experiences, to challenge and to alter the orthodox trauma narrative of Aum Shinrikyō as exclusively a social evil external to Japanese society and an enemy to be excluded from it. Towards the end of the article, we discuss the broader significance of this case study and suggest that in light of recent societal and technological developments, the role and scope of dialogical intellectuals as carriers of trauma are changing and possibly expanding.
\end{abstract}

In accordance with cultural convention, all Japanese names appear in standard Japanese order of last name followed by given name, with the exception of the lead author.

Rin Ushiyama

ru210@cam.ac.uk

Patrick Baert

pjnb100@cam.ac.uk

1 Department of Sociology, University of Cambridge, Free School Lane, Cambridge CB2 3RQ, UK 
Keywords Aum Shinrikyo · Films · Intellectual authority · Japanese culture · Novels · Religion · Terrorism

This article contributes to sociology of intellectuals and cultural trauma theory through a case study of the aftermath of the 1995 Tokyo sarin incident, the worst terrorist attack to take place in Japan in the post-War period. The attack, in which members of the millenarian religious movement Aum Shinrikyō spread sarin gas across the Tokyo subway system, killed thirteen people, and injured more than six-thousand people in a single morning. The terrorist attack, combined with Aum's past crimes and controversies, later came to be known as the Aum Affair (Oumu jiken) in public discourse.

This article has two aims. Firstly, we propose to understand the Aum Affair as a case of cultural trauma and to assess its impact on Japanese society. To do this, we reconstruct how predominant interpretations of the Aum Affair arose in the aftermath of the Tokyo attack. At the same time, we also highlight the lasting consequences of the Aum Affair as cultural trauma. Although trauma construction often has a therapeutic effect on the victimized collectivity, the consequence is not necessarily conciliatory or conclusive. Cultural trauma can encourage division among social groups, especially between identified groups of victims and perpetrators, leading to prolonged tension and social pain (Eyerman, Alexander, and Breese, 2011). As we demonstrate, Aum believers and ex-members - who themselves were not involved in Aum's militarization program or other crimes and controversies-were objects of social criticism, harassment, and exclusion after the criminal elements of the organization were arrested.

The second aim of this article is to refine theoretically the role that intellectuals play in "trauma work" - the construction of trauma narratives. Current existing literature has focused on the role of intellectuals in constructing lasting interpretations of events as social carriers of trauma, but has not sufficiently addressed the different types of intellectual action that produce different trauma narratives. We offer the dichotomy of "authoritative intellectuals" and "dialogical intellectuals" as two genres of intellectuals who engage in distinct kinds of trauma work. Unlike authoritative intellectuals, who use their expertise or cultural authority to narrate trauma, dialogical intellectuals enter into dialogue with local actors to produce open-ended, polyphonic trauma narratives. We offer a case study of two dialogical intellectuals - novelist Murakami Haruki and film director Mori Tatsuya — who sought to challenge the established trauma narrative of the Aum Affair through a dialogical method. By engaging with victims and perpetrators of the sarin attack, they challenged the symbolic representation of Aum as an absolute evil that is external to Japanese society, a predominant theme in the orthodox trauma narrative. They also opened up the possibility for reconciliation between victims and perpetrators. It is our contention that dialogical intellectuals - by virtue of their dialogical method - can help to open up, diversify, and add nuance to fixed and established trauma narratives.

\section{Cultural trauma and intellectuals}

The concept of cultural trauma is fundamental to this study. Cultural trauma theory holds that certain historical events have indelible and enduring effects on collective 
identity, as they represent an "acute discomfort entering into the core of the collectivity's sense of its own identity" (Alexander 2004, p. 10). As social actors and institutions seek to confront this threat, the event is taken as having a degree of cultural and historical permanence. Cultural trauma theory rejects naturalist theories of trauma that assume large-scale events such as war and atrocities have an automatic negative effect on the collective. Instead, cultural traumas are "made, not born" (Smelser 2004, p. 37). It is only when actors and institutions successfully mobilize cultural codes (such as the binaries of good and evil, victims and perpetrators) through discourse that social collectivities remember certain events as historically important, while memories of other large-scale events are forgotten or repressed when such discursive labor is absent. "Trauma work" is also inherently competitive, as stakeholders struggle over what trauma narratives are legitimate and lasting, what the spatial and temporal frames of the event are, who are defined as victims, and who is held morally responsible for wrongdoing.

In this sense, cultural trauma is qualitatively distinct from psychoanalytic notions of trauma (Caruth 1996; LaCapra 2001): unlike psychological trauma, which is a direct and overwhelming assault on the individual psyche, cultural trauma is created through the "symbolic extension" of victimhood from the individual to the collective, and primarily experienced vicariously through various mediated forms, such as narratives, testimonials and witness accounts, news reports, photographs, video, film, theatre, commemorative ceremonies, monuments, museums, and propaganda. Cultural traumas, when successfully constructed, can profoundly influence the collective memory of communities. "Trauma time" disrupts historical continuity, marking a fundamental break from the past and affects future outlook; it can also provide a foundational point of reference for collective identity. The symbolic impact of such traumatic events may also lead to enduring pain, indignity, and animosity, as trauma construction creates new identities and boundaries, accentuates difference, and justifies the exclusion of the "Other." As Jeffrey Alexander and Elizabeth Butler Breese note, "trauma construction so frequently crystallizes polarizing narratives, exacerbates conflict, and leads to even more suffering in turn" (Alexander, and Breese, 2011, pp. xxxiii).

Intellectuals, along with other actors, groups and institutions, have a central role in the struggle over trauma narratives. Intellectuals are a key "carrier group" of cultural trauma, as they utilize their privileged positions as knowledge holders to speak to the public to narrate the significance of historically significant events such as war, atrocities, and terrorist attacks (Alexander 2004; Eyerman 2001). Although a number of studies demonstrate the role intellectuals play in constructing trauma narratives and collective memory at large (Alexander 2012; Baert 2011; Bartmanski, and Eyerman, 2011; Eyerman 2001, 2011), many existing studies have implicitly or explicitly relied on Mannheim's (1997[1936]) and Shils's (1958) conception of intellectuals as "freefloating" figures capable of accessing the sacred realm as secular prophets. Instead, we develop and refine a new concept of intellectuals whose performative role is to contribute to shared understandings of cultural trauma through dialogical engagement with local actors, rather than to dictate authoritative accounts to the public. To do this, we offer an ideal-typical distinction between authoritative intellectuals and dialogical intellectuals.

In our definition, authoritative intellectuals narrate trauma from an assumed privileged social position, speaking from "above" society. Often benefiting from a privileged 
parcours and from having been trained in high status disciplines such as philosophy or mathematics, they presume superior knowledge of history and politics, or they may even claim to have philosophical insights into the human condition that explain the causes and consequences of traumatic events to the general public. There is a strong moral dimension to their public interventions, exhibiting character and charisma rather than expertise. Generally, authoritative intellectuals perform as "free-floating" figures (Alexander 2011, p. 197) independent from external sources of authority such as the state or party (Baert, and Shipman, 2012, p. 189), which enables the intellectual to take up a "prophetic role" (Bourdieu 1991, p. 667). Authoritative intellectuals often provide monological trauma narratives; these are close-ended interpretations, often involving moral judgments whereby the intellectual positions him- or herself as the arbiter of truth. Both Jean-Paul Sartre and Bertrand Russell were archetypal examples of authoritative intellectuals. Drawing on a privileged social and educational trajectory and trained in high-status disciplines at the very best institutions, each developed distinct trauma narratives - Sartre, for instance, about the Nazi-occupation in France and colonization, Russell about the First World War and warfare in general, and both in relation to Vietnam (Baert 2015).

By contrast, dialogical intellectuals take local actors as legitimate sites of knowledge and use their voices to inform their ideas. Unlike authoritative intellectuals, dialogical intellectuals operate "alongside" the public, engaging in dialogue with participants directly to produce knowledge. To this end, we identify three different types of dialogical intellectual action. Firstly, dialogical intellectuals can engage in dialogue and direct exchange of knowledge with local actors and communities, resulting in mutual understanding and education. This is the kind of dialogical intellectual action Michael Burawoy advocates as "public sociology" (Burawoy 2005). Secondly, the intellectual work itself can be dialogical in content and argument, as it seeks to produce, polyphonic, open-ended interpretations over monological narratives. For example, the work could consist of interviews that contain contradictory or inconsistent accounts and perspectives without resolving the accuracy or truthfulness of those statements. Bourdieu's conviction that "simplistic and one-sided images ... must be replaced by a complex and multi-layered representation capable of articulating the same realities but in terms that are different and, sometimes, irreconcilable" was central to his later political interventions as a public intellectual (Bourdieu et al. 1999, p. 3). ${ }^{1}$ Similarly, Richard Sennett has for decades highlighted the pernicious effects of contemporary capitalism on individual lives through a dialogical method (Sennett 1998, 2012). Thirdly, the intellectual product can be a record or collection of dialogue among local participants, which is disseminated for public consumption. In this example, the intellectual situates herself as a participant observer standing alongside local actors, to collect and disseminate cases of dialogical interaction. As we show in the case study, Murakami engages in the second type of dialogical action, while Mori displays both the second and third types of dialogical intervention. Because of their mode of public engagement, we contend, dialogical intellectuals can create dialogical and polyphonic trauma narratives that, instead of imposing authoritative interpretations, and can help to introduce nuance, uncertainty, and contradictions to interpretations

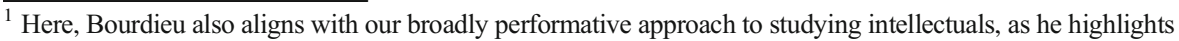
the performative dimensions of language (specifically symbolic capital) as the legitimation of social order (Swartz 2013, pp. 85-89) and sees the transformative potential of intellectuals in challenging domination legitimated through symbolic violence. For studies of public intellectuals from a performative perspective, see Baert (2015) and Ushiyama (2014).
} 
of cultural trauma while potentially helping to alleviate the polarizing distinction between victims and perpetrators. Our notion of the dialogical intellectual has some similarities with, for example, Donald Levine's "dialogical turn," in which competing sociological schools come into dialogue through a commitment to philosophical pluralism (Camic, and Joas, 2004). Nonetheless, as we clarify, our use of the dialogical intellectual is specific to the discussion of public intellectuals, and is different from existing applications of the concept of the dialogue. Here, we highlight four points.

Firstly, we offer the distinction of authoritative and dialogical intellectuals in contrast to Bakhtin's (1984) analysis of monological and dialogical narratives. Certainly, Bakhtin's reading of the novel is illuminating for understanding narrative genres within different forms of intellectual intervention, as is James Clifford's innovation of Bakhtin in differentiating forms of ethnographic authority (experiential, interpretive, dialogical, and polyphonic) (Clifford 1983). ${ }^{2}$ Bakhtin's concepts have been successfully applied in feminist literary criticism, to identify the novel as a site for resistance and rebellion in which polyphony deprivileges "the monologic authorial voice" (Kehde 1991, p. 28; see also Bauer 1988; Bauer, and Jaret McKinstry, 1991). However, what we wish to draw attention to in our dichotomy is not only a categorization of different narrative genres, but also the types of social interactions the intellectual engages in vis-à-vis local actors and audiences (though the social interactions and the kinds of narratives they produce are intimately related). Our dichotomy provides an analytical distinction of the kinds of "work" intellectuals engage in, as well as the content of their public contributions.

Secondly, our ideal-typical distinction of intellectuals differs substantially from other categorizations. Crucially, we focus our attention to intellectuals as carriers of cultural trauma, rather than provide a general typology of intellectuals as such (although we will conclude with considerations for the usefulness of this distinction beyond trauma). Nonetheless, the categories we offer can be compared usefully with existing typologies of intellectuals by Gramsci, Bourdieu, Bauman, as well as with Burawoy's discussion of disciplinary divisions within sociology. Gramsci's (1971) “organic intellectual," who shares the class background as the people he or she represents, is similar to our dialogical intellectual in promoting a more grounded, democratic participation in the discussion of ideas and political goals. However, Gramsci envisaged the organic intellectual to engage in counter-hegemonic struggles through the party: these struggles are not necessarily grounded in dialogue and polyphony as such. For this reason, Bourdieu dismissed organic intellectuals as "merely self-appointed spokesmen of the proletariat' (Bourdieu 1991, p. 668), whose self-interest ultimately prevented them from pursuing universal causes. ${ }^{3}$

\footnotetext{
${ }^{2}$ It is worth noting that the distinction between dialogical and polyphonic authority is Clifford's innovation. Bakhtin situates polyphony as the consequence of a dialogical mode of writing, rather than two distinct processes. For example, Bakhtin states that "[t]he polyphonic novel is dialogic through and through" (Bakhtin 1984, p. 40).

${ }^{3}$ Despite Bourdieu's dismissal of the organic intellectual, there is a degree of irony in the fact that Bourdieu seemed to act as one himself, "giving voice to the dominated and aiming to correct pervasive media distortions" (Burawoy, and von Holdt, 2012, p. 67). The differences between Gramsci and Bourdieu are nonetheless substantial. Gramsci saw civil society as a site for counter-hegemonic struggle, while Bourdieu's pessimistic view of civil society emphasized its "socially stratified character" (Swartz 2013, p. 183). This made a wholesale defense of civil society difficult for Bourdieu. See also Swartz (2013, pp. 169-188) for a fuller discussion. In positing civil society as an arena of contestation, not simply domination, we are inclined to agree with Burawoy and Gramsci's defense of civil society.
} 
Our ideal-types also differ from Bourdieu's more general schema in which he critiques "total intellectuals" (à la Sartre) and technocrats, and advocates a vision for the collective intellectual, an alliance of scholars working together to solve social problems (Bourdieu 1991; Swartz 2013, pp. 173-175). Bourdieu's collective intellectuals engage in dialogue amongst themselves, but the mode of public engagement tends to be one-directional. In Bourdieu's framework, the public operates more like a passive recipient of knowledge that is generated within autonomous academic fields. ${ }^{4}$

Bauman's (1987) dichotomy of intellectuals as legislators and interpreters is perhaps the closest parallel to our own, albeit with key differences. Unlike intellectuals as legislators, authoritative intellectuals do not necessarily seek to use their superior cultural status or moral and aesthetic taste to make foundational claims about knowledge and society. They are often generalists in that they speak beyond their academic training or expertise, but are not necessarily foundationalist or universalist in scope. Likewise, unlike Bauman's interpreters, dialogical intellectuals do not necessarily translate between different communities of meaning with the intention of encouraging mutual understanding and reconciliation. Rather, dialogical intellectuals act as "conduits" for local voices to enter the public arena; they are not necessarily mediators in a conflict. Whereas interpreters use technical expertise to facilitate translation work, dialogical intellectuals rely on their expert command of an artistic medium or academic genre to justify their public interventions (for example, they intervene as a writer or film maker). There are similarities between our notion of dialogical intellectual and Burawoy's categorization and advocacy of public sociology, which also infuse academic expertise with local knowledge to enrich civil debate (although our typology does not relate specifically to public sociology).

Thirdly, whilst the authoritative and dialogical intellectuals do not differ substantially by class or status, there may be certain affinities among different academic disciplines and the nature of their interventions, the methodologies they employ, and the media they choose. For example, intellectuals trained in philosophy, natural sciences, mathematics, and economics have made abstract and generalized statements that have facilitated the careers of authoritative intellectuals such as Sartre and Russell. By contrast, theoretical and methodological disputes in the humanities and the social sciences regarding oral history, ethnography, interviews, and conversation analysis have highlighted and problematized the relationship between researchers and human subjects in ways other disciplines with more positivist leanings have not. As a result, intellectuals with training in humanities and social sciences may be more attentive to dialogical methods of research and public engagement. For example, as Patricia Hill Collins demonstrates, dialogue between experts and ordinary women has been a constitutive and indispensable part of Black feminist thought (Collins 2008 [1990], pp. 33-43). Feminist social theory more broadly has also embraced the dialogical method to incorporate better the diverse voices and experiences of women, especially from marginalized backgrounds and less developed geographical regions. Dialogic feminism, Flecha and Puigvert argue, champions "equality of difference," and

\footnotetext{
${ }^{4}$ What kind of public intellectual Bourdieu himself embodied in his political interventions in the 1990s is a topic of contention (Lane 2006, pp. 5-7). Although he condemned the generalism of the total intellecutal, his foray into French politics was not always supported by his expertise as a "specific intellectual."
} 
celebrates the multiple voices of women that are otherwise repressed and rendered invisible (Flecha, and Puigvert, 2010).

Fourthly, we do not wish to suggest that authoritative intellectuals are incapable of challenging dominant trauma narratives, or that their only part is in constructing lasting narratives. Unlike Gramsci's "traditional intellectuals" who ultimately uphold hegemony in the service of the dominant class, authoritative intellectuals frequently position themselves as outsiders and impartial voices of reason, and critique the ruling elite with the purpose of speaking "truth to power" (Said 1994). Such intellectuals can thus subvert official silence on historical events or governmental whitewashing through accusation, fact-finding, and counter-narration. Their works often help to "work through" traumatic events and break the imposed silence through intellectual intervention, just as witness testimonials and confessions may help to break imposed silence of historical atrocities (Kurasawa 2009). As Ron Eyerman suggests, the act of narration itself can disrupt or subvert established discursive formations that impose interpretive frames favoring the powerful and the elite (Eyerman 2004, pp. 162-163). Edward Said spoke out against American and Israeli domination of Palestine, and engaged dialogically with the Palestinian cause as an intellectual, activist, and citizen. But he also wrote with a strong critical voice to challenge Western hegemony by writing monological essays and opinion pieces (Said 1995). Moreover, the self-imposed distance between himself and political powers was crucial to his interventions: he eschewed membership from the Palestinian Liberation Organization despite his initial close involvement with its members, commenting that "it was important to preserve my distance" (ibid., p. xxiv).

In these cases, authoritative intellectuals often appeal to their heightened sensitivity to truth (e.g., by unmasking ideology and exposing reality), rather than highlight the diverse and potentially conflicting local actors' experiences. Thus, even when authoritative intellectuals use participants' voices, experiences, and opinions, they are used in such a way to develop a coherent and singular strand of argument, instead of collating and disseminating those experiences as authentic and legitimate representations of reality. Authoritative intellectuals impose definitive counter-narratives with the aim of replacing competing narratives, rather than opening trauma narratives up to nuance and polyphony.

The Aum Affair is an illuminating case for studying how different types of intellectuals struggled over competing trauma narratives, as it is extensively documented in a plethora of television coverage, newspaper articles, and countless books on Aum Shinrikyō, although it has hitherto been a neglected event outside of Japanese studies. As we detail below, in the immediate aftermath of the Tokyo sarin attack, trauma builders including the state, the media, and intellectuals positioned Aum Shinrikyō as a crazed and destructive cult that plotted the takeover of Japan through terror. This dominant interpretive frame perceived the Tokyo sarin attack to be a formidable threat to Japanese national security and liberal and democratic values, and it positioned Aum as an external enemy to be punished and excluded. Consequently, Aum believers and ex-members, many of whom were uninvolved in the militarization process in the period leading up to the Tokyo sarin attack, gained a pariah status within Japanese society, and were subjected to widespread harassment.

Several years after the Tokyo sarin incident, however, some intellectuals began to challenge the dominant trauma framework, which demonized and excluded Aum as Japan's enemy. We highlight the works of novelist Murakami Haruki and film director 
Mori Tatsuya, whose dissatisfaction with predominant cultural representations led them to explore alternative ways of understanding the Aum affair by engaging with experiences of local actors - including victims of the sarin attack and current and ex-members of Aum. In doing so, they disrupted the exclusionary boundary between victims (Japanese society) and perpetrators (Aum), opening up the eventual possibility for reconciliation between the two divided parties.

The reason for studying Murakami and Mori lies in their distinctiveness as dialogical intellectuals in Japanese intellectual culture, as well as for their differences between each other. Both figures were exceptional within the Japanese intellectual field in attempting to introduce counter-narratives by listening to the perpetrators' points of view at all. The contemporary Japanese cultural climate, at the height of anti-cult intellectuals and anti-cult movements, made it difficult for intellectuals to frame Aum as anything other than a "destructive cult." Murakami's case demonstrates how a highstatus writer and novelist with access to means of symbolic production can pose polyphonic counter-narratives. Published by Kōdansha, one of Japan's largest publishing houses, Underground was a national bestseller that sold 270,000 copies within the first two months of release (Yomiuri Shimbun 1997a; Kavitha, and Murakami, 1997), while the sequel Underground 2: The Place That Was Promised was also a bestseller (Yomiuri Shimbun 1998). By contrast, Mori's case highlights how "material" barriers to the access of media institutions influence and regulate the struggle over meaning. Originally a television director, Mori turned to self-financed independent film making after TV production companies refused to greenlight his project to speak directly with Aum believers. It was only after he had established his reputation through his two independent films that he began to write more freely for established newspapers and magazines. Mori's case demonstrates how a virtually unknown figure outside of historically dominant social strata can establish him- or herself through trauma work. Mori's case raises questions about the relationships between intellectuals and access to means of symbolic production, their supposed "free-floating" nature, and raises the possibility that, rather than cultural capital facilitating trauma work, dialogical trauma work may provide the cultural capital to perform subsequently as public intellectuals.

\section{Aum Shinrikyō and the aum affair as cultural trauma}

Aum Shinrikyō (commonly referred to simply as Aum) was a millenarian new religious movement founded by self-proclaimed guru Asahara Shōkō. Asahara founded a small yoga class called Aum Society (“Oumu no Kai”) in 1984. Aum's belief system consisted of a syncretic and eclectic mixture of various religious traditions such as Hinduism, Tibetan Buddhism, New Age Spiritualism, and later, Christianity. As a "world-rejecting" movement (Weber 1993 [1922]), it poured scorn on consumerism and neo-liberal capitalism and it promised spiritual enlightenment through a combination of ascetic practice and mystical contemplation. Attracting the attention of youths interested in new religious movements and spiritualism, Aum grew quickly in size. In 1987, Asahara changed the name of the group to Aum Shinrikyō to reflect better his wish to turn the class into a religion (Shinrikyō translates to "Religion of Truth"). With Asahara placing himself as the omniscient guru and prophet, Aum operated on a strict hierarchy based on the level of the individual's 
spiritual attainment. Asahara ultimately envisioned Aum to spread across Japan and found a theocratic state with him as the new Emperor of Japan. Asahara claimed Aum's takeover of the state was essential to surviving the impending Armageddon (“harumagedon") (Reader 2000a; Ōta 2011).

Asahara stood for the 1990 general election along with twenty-four other candidates, but suffered a humiliating defeat. The election defeat is often cited as the turning point of Aum's trajectory, as it abandoned peaceful expansion in favor of violent, militaristic methods to achieve its religious ends; Asahara's interest shifted from salvation of the masses through conversion to takeover of the Japanese state by force (Tsukada 2011; Shimada 2012). ${ }^{5}$ After the election, Asahara organised and ordered a small team of scientists to develop biological and chemical weapons for fighting against Aum's imaginary enemy (the Judeo-Masonic conspiracy that controlled the Japanese government) and to prepare for the apocalypse (Tsuji 2011; Hirano 2011). Known as "secret work," the militarization process was conducted by Asahara's closest aides, hidden from low ranking believers. By 1994, they had succeeded in producing lethal quantities of chemical weapons such as phosgene, VX, and sarin. Aum members used these gases in attempted assassinations of Aum's critics throughout 1994, justified on the doctrine of ritual killing known as poa. According to this principle, Asahara, as an omniscient guru, could kill individuals whom he knew to commit evil deeds before they actually committed those acts: this prevented the victim from accruing negative karma and promised them a better rebirth. As an enlightened figure, the guru (and by extension his followers who carried out the orders) would not accrue negative karma from the killing either (Reader 2000a; Shimazono 1995, p. 406). Following this logic, in June 1994, Aum members sprayed sarin gas from a customised truck over the city of Matsumoto in Nagano prefecture in a deadly experiment on civilians, killing eight and injuring over six-hundred people. It was the first terrorist attack to use chemical weapons in Japan. However, as the result of mistakes in police investigation and media irresponsibility, local resident and victim Kōno Yoshiyuki was publicly accused as the culprit in the initial stages of investigation, and Aum was not suspected as the perpetrator. ${ }^{6}$

Following the Matsumoto attack, Aum maintained a relatively quiet profile until 1995, when the national newspaper Yomiuri Shimbun reported that traces of sarin residue were detected near Aum's headquarters. This publicly associated Aum with sarin production for the first time and put Aum under scrutiny (Yomiuri Shimbun 1995a). ${ }^{7}$ Aum denied sarin production and instead claimed that Aum was actually

\footnotetext{
${ }^{5}$ The sudden turn from peaceful expansion to violence is debatable and arguably exaggerated, not least because Asahara and his aides had already committed multiple murders before the election. In early 1989, he ordered the murder of Taguchi Shüji, a dissident member, and in late 1989 he ordered the murders of anti-Aum lawyer Sakamoto Tsutsumi, his wife, and their one-year old baby. Nonetheless, Asahara's former aides have stated that the election loss led to his distrust of the Japanese public, which may have subsequently contributed to Aum's turn to terrorism (Jōyū 2012; Noda 2010).

${ }^{6}$ Kōno was interviewed by the police for two days immediately after he was discharged from hospital, but refused further questioning as the police pressured him to confess. He was never arrested. Without further evidence, the media generally stopped reporting on the Matsumoto attack until after the Tokyo attack. Kōno was not exonerated until key members confessed, after which point a flurry of apologies by media outlets followed (Kōno 2001).

${ }^{7}$ The Yomiuri Shimbun article itself did not mention Aum by name, but articles by other newspapers and magazines soon mentioned the group by name, to which Aum responded by suing for defamation (Yomiuri Shimbun 10th January 1995b, p. 30; 14th January 1995c, p. 30).
} 
under attack by the American military. Ignoring Aum's protestations, the police planned to investigate Aum's premises in March, ostensibly related to a kidnapping case in February of that year. However, two days before the planned raid, on the morning of March 20th, Aum launched a coordinated attack on the Tokyo subway metro system to sabotage the police intervention. At around $8 \mathrm{am}$, five men each boarded a train on different lines carrying bags of sarin solution, puncturing them with sharpened umbrellas as they disembarked and fled. The vaporised sarin gas quickly spread through the carriages, and at one station passengers kicked the bags onto the platform in a panic, exacerbating the situation. The attack killed a total of thirteen and injured over six-thousand commuters.

The attack, which targeted the bureaucratic center of the city and paralyzed the majority of the transport infrastructure in the capital on a busy Monday morning, shocked a nation still recovering from the devastation of the Kobe earthquake just two months earlier. Even as the nation struggled to make sense of the scale and intention of the attack, the media immediately condemned the attack as "an unforgivable challenge to society" (Asahi Shimbun 1995d) and suggested that "multiple fanatics" (Yomiuri Shimbun 1995e) were likely behind the attack. Even before the media had identified the perpetrators, they adopted a framework of moral dualism, suggesting that the attack was committed by a "dark, twisted shadow lurking somewhere in this peaceful and prosperous society" (Yomiuri Shimbun 1995d). "Eeriness" ("bukimi") was a recurring word that summarized the mood after the attack, as the nation struggled to comprehend why and how such a terrible incident occurred (Asahi Shimbun 1995c, e; Yomiuri Shimbun 1995d). Responding to the news, Prime Minister Murayama Tomiichi immediately condemned the attack as "unforgivable" and vowed to bring the perpetrators to justice (Asahi Shimbun 1995f; Yomiuri Shimbun 1995f).

Despite Asahara's original intentions to sabotage and to disrupt the police investigation, the police duly raided Aum's premises as planned (although the raid related to a separate kidnapping case, not the sarin attack itself) and seized material evidence confirming Aum's involvement in both the Matsumoto and Tokyo sarin attacks. The media adopted a strongly dualistic theodicy (Simko 2012), which positioned Aum Shinrikyō as the antagonist in the Japanese trauma drama, in which the "mature civilization" was attacked by a "barbaric" terrorist organization (Yamauchi 1995). As the investigation progressed and more past crimes and conflicts came to light (which included kidnapping of ex-members and their families, lynching of dissident believers, and attempting to assassinate Aum's critics), the term "the Aum Affair" ("Oumu Jiken") emerged as a label referring to those crimes collectively. The media consistently depicted Aum as a mysterious, murderous organisation ("satsujin shüdan"), the motives of which were beyond rational comprehension. To one commentator, Aum existed on a plane of "deep darkness beyond common sense and rational thought" (Asahi Shimbun 1995i). As Aum's involvement in multiple murders and terrorist attacks became clearer, the government also explicitly adopted this Manichean frame of moral struggle. Nonaka Hiromu, Chairman of the National Public Safety Commission, likened the Aum Affair to a "war between countries," in which the very existence of the Japanese nation-state was at stake (Yomiuri Shimbun 1995h).

Public interest in the Aum Affair remained high for many months. In the first week after the Tokyo attack, television programs dedicated to Aum Shinrikyō hit record 
ratings (Yomiuri Shimbun 1995g). After Asahara was eventually arrested on May 16th, "the six network channels in Tokyo produced a total of more than one hundred hours of Aum coverage" (Hardacre 2007, p. 175), to which more than $77 \%$ of viewers tuned in (ibid., p. 177). The incessant national media coverage of Aum undoubtedly contributed to the creation of the event as a cultural trauma, not simply a local tragedy. Yet, it is necessary to recognize that these trauma narratives were created and disseminated primarily by media institutions, not the victims themselves. Graphic accounts of survivors were important to illustrate the extent of the attack, but the media framed these in a predominantly monological manner to trace the details of how the attack unfolded (Asahi Shimbun 1995a, b). Moreover, media coverage tended to devote more attention to the perpetrators than the trauma of victims. ${ }^{8}$

Throughout the initial period of intense media coverage, public intellectuals played an instrumental role in framing Aum as an anti-social cult, while they debated with top Aum members who appeared on television regularly to claim their innocence (Gardner 1999 , p. 222). Academics from various fields participated in elaborate debates to discuss issues such as Aum's "brainwashing" and "mind-controlling" techniques (which included solitary confinement, physical torture, playing Asahara's sermons at loud volumes, and forcibly administering hallucinogens to induce mystical experiences), Aum's strict religious hierarchy, and its continuing threats to society. Journalist Egawa Shōko, who had consistently been critical of Aum as an anti-social cult since the late 1980s (Egawa 1991, 1995), received wide praise for her cutting criticism of Aum's recruitment strategies and training methods as well as the believers' blind obedience to the authoritarian leader. In alliance with activists such as Steve Hassan, a "deprogrammer" for the American anti-cult group Cult Awareness Network, and Takimoto Tarō, a long-time anti-cult lawyer and activist, these authoritative intellectuals shaped an understanding of Aum as a harmful entity that has grown out of, but has turned against, Japanese society (Reader 2001, pp. 229-230). Providing a typically authoritative analysis, philosopher Umehara Takeshi speculated that Asahara's poverty-stricken upbringing and physical disability (Asahara was blind in one eye), for which he was subjected to "every kind of humiliation," led to a build-up of immense ressentiment. After failing to take over Japan as a politician, Asahara used Aum as a vehicle to exact revenge on Japanese society (Umehara 1995). In an alternative interpretation, novelist Takamura Kaoru described Asahara as a "formidable conman." There was nothing credibly religious about Aum: it was a fraud "from start to finish" (Asahi Shimbun 1995k). Such analyses often identified and excluded Aum as a pathological symptom of contemporary society, a "distorted mirror image" that reflected the dissatisfactions of youths towards contemporary values of capitalism and consumerism (Asahi Shimbun 1995g). The metaphor of Aum as a pathology justified its eradication: an editorial in Yomiuri Shimbun argued emphatically that "we must take this opportunity to mobilize any means necessary to eradicate this dangerous disease from the roots" (Yomiuri Shimbun 1995j). Commentators also drew frequent comparisons between Aum and Nazis (Asahi Shimbun 1995j); it was a salient comparison not simply because of the significance of Nazism as a metonym for evil (Alexander 2012), but also because sarin

\footnotetext{
${ }^{8}$ This was one of the reasons that Takahashi Shizue, the widow of a deputy station manager and a campaigner for victims' rights, began to collect and publish victims' testimonials herself. She felt that it was important to record and disseminate victims' experiences directly (Chikatetsu sarin jiken higaisha no kai 1998).
} 
gas was developed by Nazis during the Second World War (Yomiuri Shimbun 1995e) and Asahara reportedly admired Hitler as a role model for creating his own totalitarian mini-state (Yomiuri Shimbun 1995k).

Some authoritative intellectuals, many of them with training in religious studies, sought to disrupt this dualistic frame by offering counter-narratives. Shortly after the Tokyo attack, religious scholars Inoue Nobutaka, Takeda Michio, and journalist Kitabatake Kiyoyasu published a transcript of their discussions countering the simplistic frame of the "death cult," proposing a different perspective that looked at changes in youths' attitudes to religion (Inoue et al. 1995). Sociologist of religion Shimazono Susumu also pointed out the Aum members were "born of and nourished in the soil of contemporary Japan," and situated Aum within a wider universe of Japanese religious culture (Shimazono 1995, p. 382). However, these "alternative accounts of Aum ... had little if any impact upon television coverage" of the Aum Affair (Gardner 1999, p. 222).

These counter-narratives were hindered by two contextual factors that resulted in the overall erosion of public trust in the religious studies discipline. Firstly, there was criticism that the discipline was oblivious to the dangers Aum posed to the public, putting their "expertise" into question (Dorman 2012, p. 158). Secondly, some intellectuals with backgrounds in religious studies had spoken out in favor of Aum in the past. Spiritualist Nakazawa Shin'ichi had engaged in public debates with Asahara on multiple occasions, and had praised Asahara's charisma and knowledge of Tibetan Buddhism. Religious studies professor Shimada Hiromi had also interacted with Aum on a number of occasions. After media outlets began to report on Aum's possible involvement in sarin production in January 1995, Shimada inspected the building in question (upon Aum's invitation), which Aum had hastily disguised as a shrine days before the visit. After the visit, he carelessly defended Aum as innocent (Reader 2000b, p. 371). As a result, both intellectuals damaged the discipline's credibility and gave the impression that religious scholars were in collusion with so-called "cults."

Testimonies of disillusioned ex-believers also helped to cement the prevailing image of Aum as a violent, brainwashing cult and Asahara as a manipulative leader. They disclosed in graphic detail some torture methods Aum used to silence and re-educate dissidents. Such testimonies also helped to distance ex-members from their experiences at Aum, as they claimed they were brainwashed at the time and not in control of their actions. Over the course of several months, the media redrew the boundaries to exclude low-ranking ex-believers from the circle of "perpetrators." Some commentators suggested that Aum's ordinary members were not themselves "victims" but nonetheless deserved some sympathy, and argued they should be encouraged to reintegrate back into society (Asahi Shimbun 1995h, i).

These developments gradually shifted the criminal and moral responsibility from Aum as an organization to the leader and his aides. By the time of his arrest in May, Asahara had become a demonic figure. This process cemented the public image of Asahara as a "quintessentially evil" (Ducharme, and Fine, 1995, p. 1311) criminal mastermind who resided outside of the moral boundaries of the collectivity (Alexander

\footnotetext{
${ }^{9}$ The positions taken up by religious scholars were distinct from those taken up by existing traditional and new religious movements. While religious scholars tended to problematize the distinction between legitimate religions and cults, many religious establishements sought to isolate Aum as a "cult." See also Mullins (2012) for attempts to revitalize nationalist theology in the wake of the Aum Affair.
} 
2012; Giesen 2004), and justified the Manichean frame of struggle between good and evil. The media drew comparisons between Asahara and dictators such as Hitler and Mao, whom Asahara apparently admired (Sasa 1995; Yomiuri Shimbun 1995i). Asahara's erratic behavior during the trial added to the mysteriousness of his personality: Asahara initially pleaded not guilty, but his statements became increasingly incoherent before he eventually fell silent during hearings (Shimada 2012, pp. 225228). ${ }^{10}$ The public renunciation of faith by Asahara's closest disciples during their trials further added to the impression that even the perpetrators of the terrorist attacks were controlled by Asahara, and that they acted under strict orders under pain of death. ${ }^{11}$

The government's responses broadly followed the dualist frame as it pursued various legal means to dissolve and disband Aum. Following the arrests of key suspects in May 1995, the Tokyo magistrate court revoked Aum's "religious corporation" status in June, which had accorded it preferential tax rates and a degree of public legitimacy. However, Aum continued to exist as a civil, voluntary organization ("nin'i dantai"), under the constitutional right to freedom of association and freedom of religious belief, resulting in social unease that the group might initiate another large-scale terror attack. Consequently, to disband the group for good, the government moved to apply the AntiSubversive Act to Aum towards the end of the year. The Anti-Subversive Act is a repressive law established in 1952 in the context of the Cold War, originally designed to curtail Marxist guerrilla activities. It enabled state authorities to use force to dissolve and outlaw anti-social, destructive groups (Reader 2001, p. 228). The application of the Act to a group, let alone a religious movement, was without precedent, and provoked criticism from liberal groups who argued it amounted to religious persecution (Asahi Shimbun 19951). The government's application was ultimately unsuccessful, as the Public Security Examination Commission, an independent body affiliated with the Ministry of Justice, rejected the government's application in 1997, judging that the necessary criteria for applying the Act had not been fulfilled. In response, the government enacted the Organizations Regulation Act ("Dantai Kisei ho"”) in 1999, making it possible for the Public Security Intelligence Agency to monitor Aum and its successor organizations continuously and conduct regular searches of their premises. The Organizations Regulation Act has been applied and extended to the present day to Aum's successor organization, Aleph, and to Hikari no Wa, which split from Aleph in 2007 after an internal power struggle (Baffelli 2012).

Aum continued to be viewed as a continued threat to society to be excluded and eliminated throughout the late 1990s and into the 2000s. The enduring public animosity towards Aum was no doubt influenced by Aum's confrontational stance in the immediate aftermath of the attack, as high-rank disciples appeared on television daily to claim innocence and accuse the police of religious persecution. Even after the culprits

\footnotetext{
${ }^{10}$ Since the trials began Asahara's mental health seemingly deteriorated, his testimonies becoming more incoherent and rambling until he eventually fell silent. While some lawyers called for the trial to be halted due to suspected mental illness, the court-appointed psychiatrist judged him to be sane and "faking illness." See Mori (2012 (vol.2), pp. 300-339) and Aonuma (2007, pp. 468-485).

${ }^{11}$ The Aum Shinrikyō Families Society, which represents family members of Aum members and ex-members, released a statement in 2011 requesting the execution of twelve Aum culprits sentenced to death be halted, not including Asahara. The group has argued that the culprits were all under the influence of "mind control" by the manipulative leader. The full statement can be viewed (in Japanese) at http://aum-kazoku.boy.jp/?page_ id=128, accessed February 2015.
} 
confessed and were found guilty, Aum representatives refused to offer a formal apology for the crimes until 2000 under the new leadership of former spokesperson Jōyū Fumihiro, under the new banner of Aleph (Jōyū 2012, pp. 176-178). In this social context, the dominant trauma narrative legitimated the exclusion of those who remained in the organization. Across the country, local resident groups protested for the closure of Aum communes and eviction of Aum tenants, and many local municipalities refused to accept resident records of Aum members (a legal requirement in Japan to register for municipal tax) (Egawa 2006 (vol. 1), pp. 89-101; Reader 2001, pp. 228-229). School boards also initially barred children of Aum believers (including Asahara's children) from attending school (Egawa 2006 (vol. 1), pp. 107-113; (vol. 2), pp. 343-352).

\section{Commemoration}

Commemoration of the Aum Affair has been complex. Commemoration ceremonies at the subway stations have adopted a tragic, rather than dualist, theodicy with an emphasis on contemplation for the dead rather than accentuation of moral divisions (Simko 2012). Every year on the day of the attack at 8 am, the Tokyo Metro company observes a minute of silence at a memorial ceremony at each of the affected stations. The annual memorial service, however, is closed off to the public and attended only by Metro employees of each station. This was designed in consideration for those who did not wish to remember the attack while commuting, as well as to avoid disruption to the daily schedule. (Asahi Shimbun 1996). Station managers have vowed that the tragedy will never be repeated, but they have tended to emphasize the need to ensure passenger safety and to keep the memory of the attack alive through quiet prayer, rather than explicitly condemn the perpetrators (Yomiuri Shimbun 2000b, 2004; Asahi Shimbun 2010).

In lieu of large-scale ceremonies on the anniversary date, the metro company has designated the station office of the six affected metro stations as a sacred space where anyone can visit to offer prayers and flowers throughout the day. The station office, physically separated from the usually prosaic space of the metro station, has served as a temporary sacred site that has enabled visitors to offer prayers for the dead without too much disruption of daily routine. The room is decorated with funerary symbols such as flower offerings, a wooden structure resembling a gravestone, and the signing of the register. The site has primarily encouraged contemplation for the dead, rather than condemnation of perpetrators, and has acted to prevent the "weathering" (füka) of memory of the attack.

The act of flower donation at Kasumigaseki station has also gained political significance. The Prime Minister, and on other occasions the Chief Cabinet Minister, has historically visited the station to offer flowers to the dead on important calendrical years: the fifth, tenth, fifteenth, and twentieth anniversary dates (Asahi Shimbun 2000, 2005; Yomiuri Shimbun 2010, 2015a). Aum's representatives (later under the name of Aleph) have also visited Kasumigaseki on a regular basis to issue apologies and to offer flowers to the dead (but only after 2000), adding to the symbolic significance of the use of subway stations as de facto official commemorative sites. (Yomiuri Shimbun 2000b; Asahi Shimbun 2015). In 2015, over a thousand attendees came to offer flowers and sign the register (Yomiuri Shimbun 2015b). 
Victims of the Tokyo attack have also organized commemorative events separately. Led by Takahashi Shizue, the widow of a deputy station manager, the Subway Sarin Incident Victims' Society has held annual gatherings such as annual press conferences (usually after Takahashi's visit to Kasumigaseki station where her husband was killed), public lectures, and symposia to commemorate the event, prevent the collective memory from weathering, and to appeal for better legal and financial support for victims. Actions of the Victims' Society are also illustrative of the gulf between individual trauma and cultural trauma narratives. Distancing themselves from media narratives that placed blame on Aum alone, members of the Victims' Society have frequently criticized the state's failure to circumvent Aum's militarization process in the years leading up to the Tokyo sarin attack and voiced discontent with the lack of statefunded support of victims (Chikatetsu Sarin Jiken Higaisha no Kai 1998; Takahashi 2008).

The Japanese government has been reluctant to stage official commemorations, in spite of its initial appropriation of the attack as a national trauma. Many of Aum's properties, including the headquarters, were quickly razed to the ground, leaving only a small cenotaph for the dead. There have been minimal attempts by the state to institutionalize the memory of the Aum Affair in the form of ceremonies, museums, or monuments. A potential reason for this is the government's reluctance to offer statefinanced reparations for victims of Aum's crimes until the enactment of the Victims Relief Act of 2008, which came into being after years of extensive lobbying by the Victims' Society. Until 2008, the state's long-standing position was that victims should seek compensation from perpetrators directly, not rely on public funds for relief. It is possible that the state shied away from official appropriations of the trauma for fear it could strengthen the case for state compensation and that the official visits to a civic site of commemoration represented a political compromise that demonstrated attention but not commitment. Furthermore, state institutions may have been reluctant to address formally the uncomfortable facts surrounding Aum Shinrikyō, such as the Tokyo Metropolitan Government's decision to recognize Aum as a religious corporation amidst protests by believers' parents, the false accusation of Kōno after the Matsumoto attack, and the police's slowness in investigating Aum earlier in 1995 even after evidence of sarin production emerged.

Mass media coverage, including commemorative TV programs and documentaries, have largely been responsible for reproducing the Manichean interpretation of the Aum Affair. The tropes of brainwashing, mind-control, cults, and terrorism have also become staples in popular culture (Baffelli, and Reader, 2012, pp. 2-3). Comic books such as Urasawa Naoki's 20th Century Boys, serialized between 1999 and 2007, have reproduced the "explanation of "cults" as the products of evil masterminds who trick people into believing their lies" (Thomas 2012, p. 138).

Various forms of commemoration and symbolic representations have helped to consolidate the Aum Affair as a point of historical disjuncture in the Japanese metanarrative, a "watershed moment" that marked the beginning of "post-Aum" Japan (Reader 2001, p. 226). If the trauma and the destruction of the Second World War had paved the way for Japan's subsequent economic recovery (Dower 1999), the trauma of the Aum Affair put the post-War national myth of happiness through economic growth into question. For many commentators, the Aum Affair was a violent crystallization of anti-materialist and anti-capitalist impulses that had been repressed throughout the economic boom of the post-War era. For example, sociologist Yoshimi (2009) situates 
the Aum Affair as the end of the half-century "Post-War era" since 1945, as the national ideal of happiness through economic growth came under attack. As he argues, the Aum Affair ushered in a new, post-modern condition, which he calls the "post 'Post-War' era", marked by individualism and future uncertainty.

The interventions of two intellectuals stand out at a time - during the late 1990s and early 2000s — when the orthodox trauma narrative portrayed Aum as a dangerous cult and Asahara the embodiment of evil. Murakami Haruki, a best-selling novelist, published his first non-fiction work in a two-part collection of interviews, while Mori Tatsuya made his debut as an independent filmmaker as he documented how the media covered Aum, and revealed what Aum looked like in day-to-day life. Mori subsequently produced a sequel film and a non-fiction book. Although others have similarly questioned the one-sided demonization of Aum in cultural representations as authoritative intellectuals (as we saw in the case of Inoue and Shimazono), the two intellectuals are notable for introducing a dialogical angle to the Aum Affair as a cultural trauma and seeking to understand Aum members, rather than exclusively condemning them as perpetrators of a terrible terrorist attack.

\section{Murakami Haruki's Underground}

Murakami Haruki was already an established author by the late 1990s, having published a string of commercially successful novels starting in the late 1970s. The twovolume work, Underground (Murakami 1997) and Underground 2 (Murakami 1998) marked a radical change in the subject matter. In contrast to his previous fictional works, which often took place in surreal settings, the two volumes collected and edited interviews with victims and family of the Tokyo sarin incident (in the first volume) and current and ex-Aum members (in the second volume). Keeping distance with the dominant meta-narrative, which placed Aum as Japan's enemy and excluded Aum believers as the cultural "Other," Murakami revisits a question that, to him, was never answered satisfactorily: "what actually happened in the Tokyo subway the morning of 20 March, 1995?" (Murakami 2003, p. 196). ${ }^{12}$ In doing so, he seeks "words coming from another direction, new words for a new narrative. Another narrative to purify this [existing] narrative" (p. 196) by interviewing individuals with first-hand experience of the Tokyo sarin incident, as well as Aum followers and ex-believers. Instead of using interviews to fit a grander meta-narrative of its significance to Japanese history, he begins by collecting the experiences of those whose lives were directly affected by the terrorist attack. As Murakami states,

At the beginning of every interview I would ask the interviewees about their background - where they were born, their upbringing, their family, their job (especially their job) - in order to give each a "face," to bring them into focus. What I did not want was a collection of disembodied voices. Perhaps it's an occupational hazard of the novelist's profession, but I am less interested in the "big picture," as it were, than in the concrete, irreducible humanity of each individual (p. 6).

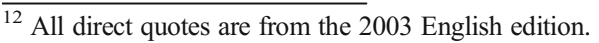


The result is a complex and nuanced collection of individual stories that do not necessarily present a coherent or singular picture. In the first volume, he is concerned with the sarin attack's victims: he interviews those who were direct victims of the attack, as well as grieving families and family members of survivors. Individual memories of the event vary greatly: some suddenly experienced their vision darkening and found it hard to breathe; others smelled a noxious smell and reacted immediately to escape. While some suffered from lasting psychological and physical trauma, others moved on quickly to resume their ordinary lives, relatively unaffected by the attack. Some experienced irreversible change: a widow recalls the shock of losing her husband while heavily pregnant with his baby (pp. 165-174), while the brother of a woman who was severely disabled by the attack recalls the pain of looking after his sister in a nearvegetative state, but celebrates her gradual recovery (pp. 76-83). In the volume, Murakami values fragmented narratives over a singular trauma narrative: "[w]hat transpired was more profound, more compounded with meanings than anything I could have imagined" (p. 205). Murakami presents the Tokyo sarin incident not as a single, traumatic blow to the Japanese nation, but a collection of thousands of stories of individual pain, sorrow, and suffering, of which he collects but a few dozen. Unravelling and isolating the individual psychological traumas of victims from the singular orthodox trauma narrative, Murakami attends to the actual suffering of individual victims rather than understanding the symbolic wound that Japan suffered as a nation.

Although Murakami displays the second dimension of dialogical intellectual action-producing a work that is dialogical in content - and uses dialogue with local participants to deconstruct the orthodox trauma narrative, he is not a "pure" dialogical intellectual. He also acts authoritatively as he constructs and advocates a new, alternative trauma narrative using his cultural authority and expertise. Employing his command of psychoanalysis and the literary genre, he offers a new trauma narrative, placing Aum not as an outsider, "an alien presence viewed through binoculars on the far shore" (p. 197), but as a return of the repressed subconscious of the Japanese psyche ("underground"), which attacked the conscious, surface world (pp. 197-199). To Murakami, Aum exists within Japanese society, not outside it: Japanese society is to light as Aum is to darkness. Although Aum constructs a different cognitive, linguistic, and symbolic universe to Japan's, Murakami sees resemblances between the Japanese psyche and Aum's beliefs; he points out that blind obedience to an existing structural order is not unique to Aum, but is present in Japanese society as a whole (pp. 206-208).

The second volume Underground 2, originally published as a magazine serial in 1998, directly follows the concerns raised in the first volume, as he tries to understand why Aum Shinrikyō arose: his intention is to open up the "'black box' ... which suddenly, from out of nowhere, made an assault on the everyday" (p. 213). Although he does not interview the actual culprits of the attack, Murakami speaks to low-ranking members, many of whom were believers at the time of the attack. Many of them had left the group, but some had decided to stay in the organization (some had also left after the interview). As with the first volume, he aims for coherence through diversity: his goal is to convey "not one clear viewpoint" but to gather "flesh-and-blood material from which to construct multiple viewpoints" (p. 215, emphasis in original). Instead of condoning or condemning their actions, Murakami listens to the motivations for why they joined, enquires what life was like at the commune, challenges their views on guilt and responsibility, and asks why they left (if they did, and if not, why not). 
The interviewees confirmed that Aum used "brainwashing" techniques and physical torture, including solitary confinement and forcible administration of LSD in an initiation ritual (pp. 251-260, pp. 298-304). Multiple accounts corroborate Aum's sinister characteristics, as a young woman recalls being sexually approached by Asahara, and later having two years of her memory erased by electro-shock (pp. 285-294). Still, Murakami breaks down the stereotype image of the crazed cult worshipper by introducing the interviewees as varied and interesting characters: some were never fully convinced of Aum's claims in the first place and had doubts about Asahara's teachings, while others, who were not involved in Aum's militarization program, still held mixed feelings towards their guru despite admitting that the Tokyo sarin attack was abhorrent (pp. 239-250). Unlike the sensational media reports that emphasized brain-washing practices and torture methods, the interviews show Aum to be far less restrictive and "cult-like" in some respects. One believer commented that it was possible to suggest changes to the guru's initial orders-(p. 244), while another wryly remarked that Aum was "[n]ot much different from the secular world," as Asahara favored Tokyo University graduates and beautiful women (p. 255).

As with the first volume, Murakami's dialogical method deconstructs the orthodox trauma narrative before he offers a new, authoritative interpretation of why so many intelligent youths with bright prospects joined Aum. According to Murakami, the Aum elites, with high levels of education and technical expertise, "couldn't help having grave doubts about the inhumane, utilitarian grist mill of capitalism and the social system in which their own essence and efforts - even their own reasons for beingwould be fruitlessly ground down" (p. 307). The sense of anomie and powerlessness in the corporate ladder pushed those individuals to Aum, a sanctuary that provided the possibility for self-improvement, on the condition that they followed Asahara's words as truth and abandoned the capacity for self-criticism. As he suggests in the conclusions of both volumes, Aum is an unwanted outcome - the repressed subconscious - of an excessively materialist society that excludes those who do not embrace the norms of capitalism, but it is not a foreign enemy to be rejected. The people who joined Aum are "not abnormal; they're not disadvantaged; they're not eccentrics. They are the people who live average lives ...who live in my neighborhood" (p. 309).

The Underground series was reviewed positively by critics (Asahi Shimbun 1997; Yomiuri Shimbun 1997b, 1999), although critics such as Ian Hacking (2000) have questioned whether it was ultimately successful in uncovering anything specifically "Japanese" about the terrorist attack. There are also methodological weaknesses in Murakami's works, as the interviewees for both volumes were arbitrarily and unsystematically selected by his assistants and editors. The abstractions he makes from interviewing low-ranking believers are also problematic, as many of them were ignorant of the militarization process; their experiences do not shed light on Aum's darkest secrets. Moreover, the detached attitudes expressed by low-ranking believers do not help to explain why high-ranking believers committed multiple murders and terrorist attacks, despite the doubts they may have harboured. Hence there is a disjuncture between the dialogical content of his interviews, and the monological conclusions he draws: if some believers were detached and incredulous of Aum's claims, why were they so obedient and unreflexive in carrying out abhorrent crimes? Answers may lie elsewhere, outside of Murakami's texts. For example, Hayashi Ikuo (2001), one of the culprits of the subway attack, characterised his actions as a mixture of blind faith and 
coercion. At the same time as believing the guru's actions to be good, he was fully aware that backing out or disobeying orders would result in his and his family's death. In interviewing low-ranking members and ceding interpretive authority, Murakami ends up privileging relatively unimportant voices over arguably more important ones (testimonies of senior members and culprits) for uncovering the group dynamics that led to Aum's turn to terrorism.

\section{Mori Tatsuya's $A, A 2$, and $A 3$}

While also acting as a dialogical intellectual, Mori Tatsuya's intervention as a public intellectual differs significantly from Murakami's. Unlike Murakami, Mori was unknown in public discourse until his debut as an independent film director in A (Mori 1998). His critique of the media coverage of Aum is also arguably more direct and provocative than Murakami's. A follows the daily life of a young believer called Araki Hiroshi, who is entrusted with the organization's public relations after the arrest of key members. By gaining the trust of Araki and his fellow members, Mori captures the daily life inside the organization, thereby dispelling the myths surrounding Aum believers and challenging the Manichean frame dividing Aum and Japanese society. As Mori states in a subsequent commentary book (Mori 2002), he endeavored to reveal a side of Aum inaccessible through conventional television coverage and to critique the media coverage as one-sided, inaccurate, and misleading.

The social context behind the creation of the film is crucial to Mori's choice of medium. As a freelance TV director, Mori initially conceived of a television documentary that was detached from the hackneyed trope of Aum as a dangerous cult. However, TV production companies refused to commission the project as it was too controversial: it did not fit well with the condemnatory tone required of Aum-related coverage, and it would be seen as being too sympathetic to Aum (Gardner 1999; Mori 2002). Having been denied access to this means of symbolic production, Mori opted to self-finance the project as an independent film instead, and he eventually completed the film with the help of producer Yasuoka Takaharu, who doubled as second cameraman.

Critiquing the widespread media representations of Aum, Mori challenges the supposed objectivity of the camera, that whatever is captured on film must be "true" and "factual." As an experienced TV director and an expert on documentaries, Mori argues in the commentary book that any video footage can be edited in post-production to induce different impressions (Mori 2002, pp. 215-216). Whatever camera footage presented as "fact" is merely a manipulated representation of reality. By rejecting the false objectivism of the camera, Mori adopts a perspectival shift that is central to the film: itself a subject with limited horizons, Mori's camera captures life in Aum from within the organization, as well as on level with its participant subjects. Although Mori does not fully embed himself into Aum's lifestyle, he builds up enough trust with believers to engage in candid conversations about why they continue to believe in Asahara as an omniscient guru, and whether they still believe in Aum's doctrines. By treating Aum believers as legitimate sites of knowledge and information - and by respecting their perspectives without prior prejudice-Mori shows Aum believers to be reflexive and much less "brainwashed" than earlier media reports suggested. 
The deliberate perspectival shift also enables Mori to reveal disingenuous and questionable practices by some media personnel behind the camera. In a scene near the beginning of the film, a reporter from a national TV network approaches Araki for permission to film. As Araki asks whether he is being filmed at the moment and denies permission for the footage to be used, the reporter replies that she does not know if he is being filmed, and asks whether they can use the footage anyway if the camera was running, on the basis of "journalistic freedom" ("shuzai no jiyu"). On another occasion, outside the Kamikuishiki headquarters, a reporter approaches Araki, claiming he has secured permission to film inside Aum's buildings from the bankruptcy trustee (an external auditor appointed to manage Aum's finances after it declared bankruptcy), and that Araki's consent is unnecessary. As Araki rebuffs the claim to say they cannot film without the permission of Aum residents living in the commune, the reporter changes his tune to admit that he was there to secure Araki's permission and that the trustee's agreement was insufficient by itself.

In a sequence that has gained a central significance in the film, Mori also unexpectedly captures a scene of false arrest. As a group of believers leave the commune, several policemen interrogate Araki and his companions on the street. As they refuse to show identification and attempt to walk away, a police officer tackles a member down to the ground, himself falling to the ground in the process. The officer claims to be hurt, and as the member lies concussed on the ground, he is arrested promptly for assault and obstruction of justice. Members of the public are spectators to the incident and later try to talk Araki and others out of Aum. In the following scene, breaking the journalistic code of non-interference, Mori hands the tape over to Aum's defense lawyer as evidence; the man is later released without charge.

Throughout the film, Mori challenges the dualistic codes imposed upon Aum-of society as good, civil, and rational, and Aum as evil, barbaric, and irrational-without condoning or defending Aum's crimes. Mori shows Aum first and foremost as a religious organization, devoted to a moral norm different from Japan's own, but hardly resembling a brainwashed terrorist group dedicated to destroying Japanese society, as reported in the media. Although the film itself lacks a clear narrative direction and thus does not impose an authoritative interpretation of the Aum Affair, Mori provides an exegesis of his motivations behind the film in his commentary book. Like Murakami, Mori questions the boundary drawn between Japanese society and Aum by asking whether or not the Japanese people are as obedient to rules and norms as some Aum believers are, as Japanese society hatefully and vengefully attacks Aum-the evil "perpetrators"—on behalf of reified "victims" (Mori 2002, p. 157, 175-176).

Unlike Murakami, whose cultural and social capital provided him access to a major publishing house and magazine, Mori was largely excluded from mainstream media outlets. Mori's limited financial resources meant $A$ received limited theatrical screening at independent cinemas. Attendance was approximated at 10,000 people as of 1999 (Mori, and Yasuoka, 2001, p. 11). While some critics reviewed the film positively (Gardner 1999, pp. 231-232), mainstream media criticised Mori as being too sympathetic to Aum (Koike 2011). He also faced protest from anti-cult lawyer Takimoto Tarō who claimed Mori was too kind to Aum believers and neglected to capture the suffering of Aum's victims: the film did not properly address Aum as "perpetrators" and Japanese society as "victims," and neglected to address questions of "mind-control" (Gardner 1999, pp. 233-234; Mori 2012 (vol. 2), pp. 110-116). Undeterred, Mori 
continued to make a sequel, $A 2$, released in 2001. Whereas the first work fits with the second dimension of dialogical intellectual action as content and argument, A2 serves also as an illustration of the third dimension of dialogical intellectual action as a record of dialogue among local participants. Throughout A2, Mori shuttles back and forth between Aum and the surrounding world as a participant observer, but undertakes no "translation work" in Bauman's sense as an interpreter.

A2 features less of Mori as a talking participant and features more heavily the conversations between Aum members and local residents. A2 focuses on the interaction between Aum members living in small regional communes and local resident groups protesting for their eviction and it explores the potential for reconciliation and mutual understanding. In one instance, a local Aum surveillance group agrees to disband after befriending and reconciling with Aum members, concluding that they no longer pose a threat to the local community. While the residents dismantle the surveillance tent next to the commune building, they seem to give a qualified endorsement of the religious commitments of the group. Nonetheless, reconciliation with Aum members seems a distant possibility for the rest of Japanese society. In one scene, a real estate broker draws public scrutiny for employing Aum believers. As television crews wait outside, an Aum representative heads to the company to apologize to the company and local government officials, promising to quit the jobs and never return to their town. As a reporter approaches the representative and Mori for comment, Mori leaves the site, apparently exasperated. $A 2$ received a wider theatrical release than $A$ did, was critically acclaimed, and won an award in the Yamagata International Documentary Film Festival, subsequently securing Mori's position in the Japanese civil sphere as a liberal public intellectual (Gardner 2002, pp. 340, 343).

Since directing A2, Mori has turned to writing non-fiction books and followed up his contributions on Aum with A3 (2012), a series of essays that challenges the demonization of Asahara as a psychopathic and manipulative leader in popular media and seeks to uncover the "true" version of Asahara. He continues to employ a broadly dialogical method, interviewing people who knew Asahara during childhood or in the years before he established himself as a guru. Also speaking to and exchanging letters with Asahara's closest aides in prison, he contests the orthodox representation of Asahara as the source of evil and a master manipulator, instead suggesting that Aum's turn to violence was the result of complex social dynamics within the organization. Mori argues that Aum turned violent not because Asahara brainwashed and controlled his disciples to enact his destructive vision, but because his disciples, eager to please Asahara, presented him with possible solutions to his paranoid fears and delusions, and executed them with his approval and consent.

He also criticizes the court's finding in 2006 that Asahara was mentally fit to stand trial despite a conflicting assessment by the defense's psychiatrist, which gave the court the legal basis to continue the trial. In a further turn of events, the Tokyo High Court dismissed the appeal on purely procedural grounds (for the defense's failure to file documents on time). Subsequent special appeals to the High Court and the Supreme Court were also dismissed, finalizing the first trial's death sentence verdict without the case advancing to a higher court of appeal. Mori criticizes this decision as politically motivated, and reflecting Japan's moral impulsion to sentence Asahara to death regardless of his current mental condition (Mori 2012 (vol. 1), pp. 329-339). Although Mori continues to rely on dialogical methods to inform his views, unlike $A$ and $A 2, A 3$ 
is driven by an authoritative counter-narrative that directly challenges the image of Asahara as the evil mastermind. A3 won the Kōdansha non-fiction award, and Mori continues to write mainly non-fiction books on an array of social issues such as the critique of Japanese media, the death penalty, and discrimination against minority groups.

Like Murakami's interviews, Mori's exploration of the daily lives of Aum believers is not without limitations. Like an ethnographer on fieldwork, Mori is reliant on informants who guide and define what and who he is allowed to see. However, unlike an authoritative ethnographer, who can question and exclude things or information that he or she sees as untrue or irrelevant, Mori's suspension of monological authority limits his own critical capacity to challenge the veracity of his interviewee's claims. Moreover, like Murakami's interviewees, Mori's informants are all low-ranking ones who were not involved in the militarization process, and his ahistorical mode of inquiry reveals very little about Aum's turn to terrorism. The decision to talk with Aum members also came at the cost of excluding dialogue with Aum's victims, whose perspectives are patently absent from $A$ and $A 2$ (although in $A 3$ Mori interviews Nagaoka Hiroyuki, an anti-cult campaigner who survived Aum's assassination attempt).

\section{Conclusions}

The Tokyo sarin incident and the revelation of Aum's past crimes led to the creation of a cultural trauma known as the Aum Affair. In dealing with the shock of the worst terrorist attack in recent Japanese history, mainstream media outlets, state elites, and many intellectuals produced trauma narratives that posited Aum as a formidable, external threat that threatened Japan's core cultural and moral values. One consequence of this orthodox trauma narrative was the social exclusion of Aum members through harassment and extra-legal and illegal discrimination by some private firms, municipal councils, and state authorities. Such forms of social exclusion in turn left some Aum members unable (and often unwilling) to reintegrate back into society. In such a context, on the one hand, Murakami sought to develop new understanding of why and how Aum captured the imagination of so many people, and he offered a counternarrative that destabilized the boundary between victims and perpetrators. Mori, on the other hand, used his experience with Aum members to challenge and deconstruct the symbolic representations of Aum Shinrikyō as a menace to society, meanwhile exploring possibilities for reconciliation. Despite their different methods, they both concurred that the orthodox narrative of Aum as a social evil and Asahara as a demonic figure was insufficient to uncover why the Aum Affair occurred. Although they did not explicitly identify each other as intellectual allies, Murakami contributed a short afterword to the DVD release of $A$, comparing it to his own works and praising its unique perspective, the unsettling provocativeness of the film and abandonment of a straightforward narrative (Murakami, in Mori 1998).

The impact of their interventions is difficult to assess, as the predominant interpretive scheme of Aum as a malevolent enemy and a brainwashed cult seems to have endured over the past two decades. Nonetheless, Murakami and Mori opened up the possibility for discussions that go beyond reinforcing dominant interpretations 
espoused by the state and the media. Since Murakami and Mori's interventions, a number of works have sought to modify the dominant existing trauma narratives through the articulation of local actors' experiences: victims of the sarin attack published a collection of essays and letters detailing their experiences (Chikatetsu Sarin Jiken Higaisha no Kai 1998), while a collection of interviews with ex-Aum members has also been published in recent years (Aoki 2010). In addition, individuals affected by Aum Shinrikyō have written memoirs detailing their own experiences: examples include Takahashi Shizue, a widow of the sarin attack victim who became an active campaigner for victims' rights (Takahashi 2008), Kōno Yoshiyuki, a victim of the Matsumoto sarin incident, (Kōno 2008), and key Aum members who later renounced Asahara (Hayakawa, and Kawamura, 2005; Hayashi 2001; Jōyū 2012; Noda 2010). Although such publications had relatively limited circulation that paled in comparison to mass media coverage, they have helped to introduce varied voices to the understanding of the Aum Affair in public discourse, complicating and challenging the simplistic narrative of Japan struggling against an evil force.

As we have argued, dialogical intellectuals are well-placed to challenge dominant trauma narratives and coded representations of actors and institutions by engaging with local actors' voices and experiences. Dialogical intellectual engagement brings nuance, uncertainty, and open-endedness to otherwise fixed and institutionalized trauma narratives. Dialogical intellectuals can help to unearth local voices, pitting them against officially sanctioned versions and offering alterations to orthodox trauma narratives. Dialogical intellectuals can also help to destabilize official narratives that glorify past violence, turning them into potential trauma narratives. In film, Oppenheimer (2012) and The Look of Silence (Oppenheimer 2014) are examples that challenge the legacy of the 1965 Communist purge in Indonesia through a method not dissimilar to Mori's. In The Act of Killing, rather than providing a monological counternarrative to the official celebratory narrative, Oppenheimer follows an aged deathsquad executioner, Anwar Congo, who is hailed as a hero by the government and the local paramilitary group. Instead of confronting and accusing Anwar and other killers, Oppenheimer asks them to recreate scenes of torture and execution on film. In doing so, Oppenheimer makes himself privy to the executioner's guilt and nightmares beneath the pomp and glory of official commemorative ceremonies. Although the methods Oppenheimer employs to engage with his subjects are more manipulative than Mori's, Oppenheimer nonetheless succeeds in humanizing perpetrators as individuals haunted by their actions half a century later, rather than simply dehumanizing them as ruthless villains. The Look of Silence follows a middle-aged man name d Adi, whose brother was murdered in the purge. He meets his brother's killers and confronts them about their past actions. As the man faces the killers, many of them deny responsibility. The conversations between him and the killers (and their families) are often tense and uncomfortable, and seemingly irreconcilable. Yet, in one scene the daughter of a killer asks the man to forgive her father upon finding out about his involvement as a killer; in another scene the widow of a killer offers a brief apology, while her sons are visibly agitated upon discovering their father's history. Oppenheimer's actions, both during the making of the film (by enabling Adi to confront the killers) and in releasing the film, seek to challenge the official glorification of the Communist purge and to posit new trauma narratives through dialogical engagement at various levels. 
Beyond catastrophes, a dialogical approach may also help to shed light on "ordinary suffering" of marginalized groups and communities, as Bourdieu did in The Weight of the World (Bourdieu et al. 1999). Although not explicitly engaging in "trauma work," Bourdieu refers to the residents of a public housing project he studies as "not unlike the survivors of an immense collective disaster" (ibid., p. 6), as he seeks to bring to light the effects of systemic domination on different communities. Such a dialogical perspective can highlight multiple and potentially irreconcilable points of view-in Bourdieu's studies, between victimized immigrant communities and members of far right movements from marginalized backgrounds - without reducing opponents to simplistic binaries and exacerbating conflict. Bourdieu extends public intellectual engagement when he insists that in such an endeavour, the investigators must reflexively objectify themselves in relation to the social space they inhabit and they should explicitly address the often unequal relationship with the research subjects that dialogical situations create (Bourdieu et al. 1999; Bourdieu 2003). Bourdieu's reflexive sociology places limits to the kinds of authoritative claims an intellectual can claim with reference to social problems (for a reflexive intellectual must necessarily renounce their "independent" and "free-floating" nature), while opening up avenues to produce different and diverse forms of trauma narratives, not necessarily limited to large-scale atrocities.

There are, of course, limits. The fact that intellectuals must draw on expertise from an autonomous field in order to make political statements (Bourdieu 1991) means that they are constrained by their own prestige and authority claims. Despite attempts to reduce unequal relations between the researcher and subject, any elimination of inequality is likely to be temporary. Furthermore, dialogical intellectuals are well placed to destabilize trauma narratives through dialogical engagement with local subjects, but they are also constrained by their commitment to diversity and polyphony; that is to say, polyphony alone cannot replace orthodox trauma narratives. Murakami and Mori both used their dialogical experiences with local actors as a method to deconstruct and destabilize the orthodox trauma narrative, and they also used those experiences as the basis on which to build new, authoritative trauma narratives. Although dialogue was essential to informing and shaping their ideas for both intellectuals, their counter-narratives were themselves authoritative and monological (and drawn substantially from expertise), suggesting that the collection of polyphonic voices may not itself be sufficient to challenge dominant trauma narratives.

Finally, it is worth taking this theme of dialogical intellectuals right into the twentyfirst century. Although our case study deals with a time period before the global proliferation of Internet-based media and communications technologies such as blogs, micro-blogs, video streaming sites, and social networking sites, there are signs that such technological changes are also affecting how intellectuals engage with the public in the construction of cultural trauma. In the context of these technological innovations, individuals are faced with a much lower barrier to entry to becoming self-fashioned intellectuals - through blogging (including video-blogging and micro-blogging) or Internet-based media content distributors (for example, YouTube-based "channels"). As a result, institutions that previously acted as gate-keepers for intellectual interventions - for instance, literary agents or editors of newspapers and publishers (Baert, and Booth, 2012, p. 117) - have a lesser role to play in the regulation of the market of ideas. While this may mean that intellectuals with superior cultural status such as novelists or film directors may hold less advantage in the collection and dissemination of local experiences, this does not necessarily imply the role of dialogical intellectuals in 
narrating trauma as a whole will be diminished. The fluidity of the flow of information on the Internet may facilitate a more direct engagement between intellectuals and the public(s) that they address, as intellectuals become less reliant on traditional, onedirectional flows of information (in the form of newspaper columns, books, lectures, and television appearances) to embrace more dialogical modes of communication online. Consequently, the first and second dimensions of dialogical intellectual action-mutual understanding and education between intellectuals and their audiences, and the creation of dialogical, polyphonic content - may have a greater part to play in narrating trauma and performing as dialogical intellectuals, without recourse to traditional media that presume cultural status and expertise (such as film and publishing).

Moreover, these technological advances allow individuals to narrate trauma directly, rather than through mediating institutions such as newspapers and television networks. The responses to the Charlie Hebdo massacre and coordinated Paris attacks, in January and November 2015 respectively, are illustrative of this. While traditional media such as television broadcasters and newspapers tended to frame the attacks as a battle between the liberal, democratic, secular West and tyrannical, theocratic, and fanatical Islamic extremists, others questioned this binary on Internet-based media outlets such as openDemocracy, Huffington Post, and The Guardian's Comment is free. Although condemning the attacks in the strongest possible terms, they also pointed out the background of growing prejudice against Muslims in the United States and Europe and persistent economic inequities of immigrant communities. Many of these counternarratives, by established academics, columnists, and bloggers, were authoritative interventions in nature; nonetheless, others - including European and American Muslims relating to their own personal experiences - have intervened through online media to condemn the terrorist attacks, but also to disagree with many of the mainstream media firms' decision to reproduce Charlie Hebdo's depiction of the Prophet Mohammed a week after the attack, as well as France's decision to bomb Syria in retaliation.

We would suggest that these cultural shifts are the result of changes in the way people use different Internet-based media, not due to inherent qualities of certain information and communications technologies. The rise of such Internet-based media suggest that the struggle over meaning and the contestation over trauma narratives is no longer restricted to media elites, intellectuals and state powers, and that singular trauma narratives are increasingly difficult to sustain as a result. While we recognize that restrictions to the articulation of trauma through state repression and censorship are substantial in certain societies and communities, online communication technologies likely make trauma narration an increasingly polyphonic affair.

Open Access This article is distributed under the terms of the Creative Commons Attribution 4.0 International License (http://creativecommons.org/licenses/by/4.0/), which permits unrestricted use, distribution, and reproduction in any medium, provided you give appropriate credit to the original author(s) and the source, provide a link to the Creative Commons license, and indicate if changes were made.

\section{References}

Alexander, J. C. (2004). Towards a theory of cultural trauma. In Cultural trauma and collective identity, by J. C. Alexander, R. Eyerman, B. Giesen, N. J. Smelser, and P. Sztompka, (pp. 1-30). Berkeley, CA: University of California Press. 
Alexander, J. C. (2011). Performance and power. Cambridge: Polity.

Alexander, J. C. (2012). Trauma: a social theory. Cambridge: Polity.

Alexander, J. C., \& Breese, E. B. (2011). Introduction: on social suffering and its cultural construction. In R. Eyerman, J. C. Alexander, \& E. B. Breese (Eds.), (pp. xi-xxxv) Narrating trauma: on the impact of collective suffering. Boulder, $\mathrm{CO}$ : Paradigm.

Aoki, Y. (Ed.) (2010). Oumu o Ikite: Moto Shinja Tachi no Chikatestu Sarin Jiken kara 15 nen. Tokyo: Saizō. Aonuma, Y. (2007). Ōmu Saiban Bōshōki . Tokyo: Shōgakkan.Shohan. Shōgakkan Bunko

Asahi Shimbun (1995a). 'Tsūkin' osotta dokugasu jōkyaku, kenmei no dasshutsu. 20 March (Eve. Ed.): 14.

Asahi Shimbun (1995b). Me ga mienu, iki dekinu ... Musabetsu no kyōfu mata.. 20 March (Eve. Ed): 15.

Asahi Shimbun (1995c). Tōkyō no chikatetsu sarin jiken. 21 March: 1.

Asahi Shimbun (1995d). Dokugasu tero no sokoshirenu kyōfu (Shasetsu). 21 March: 5.

Asahi Shimbun (1995e). Oumu kyōdan no giwaku ni semare (Shasetsu). 23 March: 5.

Asahi Shimbun (1995f). Shūkan hōkoku. 27 March: 5.

Asahi Shimbun (1995g) 'Nichjō' ga yugamerareta ikkagetsu (Shasetsu). 21 April: 5.

Asahi Shimbun (1995h). Ippan shinto to hanzai, musubitsukenaide. 1 May: 22.

Asahi Shimbun (1995i). Kyōdan no fukai yami ni semare. 17 May: 5.

Asahi Shimbun (1995j). Karuto unda shakai no 'byōkon'. Oumu Shinrikyō to Tōkyō, chikatetsu sarin jiken. 7 June: 25 .

Asahi Shimbun (1995k). Takamura Kaoru san (Oumu no yami intabyū tokushū: 9). 23 June (Eve. Ed.): 2.

Asahi Shimbun (19951). Habōhō rongi wa uwasuberi da (Shasetsu). 28 September: 5.

Asahi Shimbun (1996). Chikatetsu sarin jiken, asu 1 nen. 19 March: 34.

Asahi Shimbun (1997). Andāguraundo Murakami Haruki cho (Shohyō). 6 April: 14.

Asahi Shimbun (2000). 'Anohi' e mokutō. Chikatetsu sarin kara 5 nen, Chiyoda-sen Kasumigaseki-eki. 21 March: 1.

Asahi Shimbun (2005). 'Sanjō ima mo hakkiri to' Chikatetsu sarin jiken kara 10 nen de tsuitō. 21 March: 39.

Asahi Shimbun (2010). Chikatetsu sarin jiken kara 15 nen Tōkyō Metoro 6 eki ni kenkadai. 20 March (Eve. Ed.): 1.

Asahi Shimbun (2015). Arefu Araki kōhō buchō, Kasumigaseki eki de kenka. Chikatetsu sarin jiken 20 nen. 21 March: 39.

Baert, P. (2011). The sudden rise of French existentialism: a case-study in the sociology of intellectual life. Theory and Society, 40(6), 619-644. doi:10.1007/s11186-011-9154-4.

Baert, P. (2015). The existentialist moment; the rise of Sartre as a public intellectual. Cambridge: Polity Press.

Baert, P., \& Booth, J. (2012). Tensions within the public intellectual: political interventions from Dreyfus to the new social media. International Journal of Politics, Culture, and Society, 25(4), 111-126. doi:10.1007 /s10767-012-9123-6.

Baert, P., \& Shipman, A. (2012). Transforming the intellectual. In F. D. Rubio \& P. Baert (Eds.), The politics of knowledge (pp. 179-204). London: Routledge.

Baffelli, E. (2012). Hikari no Wa: a new religion recovering from disaster. Japanese Journal of Religious Studies, 39(1), 29-49.

Baffelli, E., \& Reader, I. (2012). Editors' introduction. Impact and ramifications: the aftermath of the aum affair in the Japanese religious context. Japanese Journal of Religious Studies, 39(1), 1-28.

Bakhtin, M. M. (1984). Problems of Dostoevsky's poetics. Edited and translated by C. Emerson. Minneapolis: University of Minnesota Press.

Bartmanski, D., \& Eyerman, R. (2011). The worst was the silence: the unfinished Drama of the Katyn massacre. In R. Eyerman, J. C. Alexander, \& E. B. Breese (Eds.), Narrating trauma: on the impact of collective suffering (pp. 237-266). Boulder, CO: Paradigm.

Bauer, D. M. (1988). Feminist Dialogics: a theory of failed community. Albany, NY: State University of New York Press.

Bauer, D. M., \& Jaret McKinstry, S. (Eds.) (1991). Feminism, Bakhtin, and the dialogic. Albany, NY: State University of New York Press.

Bauman, Z. (1987). Legislators and interpreters: on modernity, post-modernity, and intellectuals. Ithaca, NY: Cornell University Press.

Bourdieu, P. (1991). Fourth lecture. Universal corporatism: the role of intellectuals in the modern world. Poetics Today, 12(4), 655-669.

Bourdieu, P. (2003). Participant Objectivation. Journal of the Royal Anthropological Institute, 9(2), 281-294. doi:10.1111/1467-9655.00150.

Bourdieu, P., et al. (1999). The weight of the world: social suffering in contemporary society. Cambridge: Polity Press. 
Burawoy, M. (2005). 2004 ASA presidential address: for public sociology. American Sociological Review, $70(1), 4-28$.

Burawoy, M., \& von Holdt, K. (2012). Conversations with Bourdieu: the Johannesburg moment. Johannesburg: Wits University Press.

Camic, C., \& Joas, H. (Eds.) (2004). The dialogical turn: new roles for sociology in the Postdisciplinary age. Lanham, MD: Rowman \& Littlefield.

Caruth, C. (1996). Unclaimed experience: trauma, narrative, and history. Baltimore: Johns Hopkins University Press.

Chikatestu Sarin Jiken Higaisha no Kai (1998). Soredemo Ikiteiku: Chikatetsu Sarin Jiken Higaisha Shukishū. Tokyo: Sanmāku.

Clifford, J. (1983). On ethnographic authority. Representations, 1(2), 118-146. doi:10.2307/2928386.

Collins, P. H. (2008). Black feminist thought: knowledge, consciousness, and the politics of empowerment. New York: Routledge.

Dorman, B. (2012). Scholarly reactions to the Aum and Waco incidents. Japanese Journal of Religious Studies, 39(1), 153-177.

Dower, J. W. (1999). Embracing defeat: Japan in the aftermath of world war II. London: Allen Lane.

Ducharme, L. J., \& Fine, G. A. (1995). The construction of Nonpersonhood and demonization: commemorating the traitorous reputation of Benedict Arnold. Social Forces, 73(4), 1309-1331. doi:10.2307 $/ 2580449$.

Egawa, S. (1991). Kyūseishu no Yabō: Oumu Shinrikyō o Otte. Tokyo: Kyōiku Shiryō Shuppankai.

Egawa, S. (1995). Oumu Shinrikyō Tsuiseki 2200 Nichi. Tokyo: Bungei Shunjū.

Egawa, S. (2006). Oumu Jiken Wa Naze Okitaka: Tamashii no Ryoshū . Tokyo: Shinpūsha.2 vols

Eyerman, R. (2001). Cultural trauma: slavery and the formation of African American identity. Cambridge: Cambridge University Press.

Eyerman, R. (2004). The past in the present: culture and the transmission of memory. Acta Sociologica, 47(2), $159-169$.

Eyerman, R. (2011). The cultural sociology of political assassination: from MLK and RFK to Fortuyn and Van Gogh. Basingstoke: Palgrave Macmillan.

Eyerman, R., Alexander, J. C., \& Breese, E. B. (Eds.) (2011). Narrating trauma: on the impact of collective suffering. Boulder, CO: Paradigm.

Flecha, A., \& Puigvert, L. (2010). Contributions to social theory from dialogic feminism: giving a voice to all women. In D. E. Chapman (Ed.), Examining social theory: crossing borders/reflecting back (pp. 161174). New York: Peter Lang.

Gardner, R. A. (1999). Lost in the cosmos and the need to know. Monumenta Nipponica, 54(2), 217-246.

Gardner, R. A. (2002). 'A' revisited. Monumenta Nipponica, 57(3), 339-348.

Giesen, B. (2004). Triumph and trauma. Boulder, CO: Paradigm.

Gramsci, A. (1971). In Q. Hoare \& G. Nowell-Smith (Eds.), Selections from the prison notebooks of Antonio Gramsci. London: Lawrence \& Wishart.

Hacking, I. (2000). What did Aum Shinrikyo have in mind? London Review of Books, October 19. 3-8.

Hardacre, H. (2007). Aum Shinrikyô and the Japanese media: the pied piper meets the lamb of god. History of Religions, 47(2/3), 171-204. doi:10.1086/524209.

Hayakawa, K., \& Kawamura, K. (2005). Watashi ni Totte Oumu towa Nandattanoka. Tokyo: Popurasha.

Hayashi, I. (2001). Oumu to Watashi. Tokyo: Bungei Shunjū.

Hirano, N. (2011). Kyōhon Rui kara Ukagaeru Kyōgaku Naiyō. In I. Nobutaka \& RIRC (Eds.), Jōhō Jidai no Oumu Shinrikyō (pp. 183-220). Tokyo: Shunjūsha.

Inoue, N., Takeda, M., \& Kitabatake, K. (1995). Oumu Shinrikyō towa Nani Ka: Gendai Shakai ni Toikakeru Mono. Tokyo: Asahi Shimbunsha.

Jōyū, F. (2012). Oumu Jiken 17-Nenme no Kokuhaku. Tokyo: Fusōsha.

Kavitha, R., and Murakami, M. (1997). The human cost: the Aum Shinrikyo victims have their say. Asiaweek 3 October. http://edition.cnn.com/ASIANOW/asiaweek/97/1003/feat5.html . Retrieved March 2016.

Kehde, S. (1991). Voices from the margins: bag ladies and others. In D. M. Bauer \& S. J. McKinstry (Eds.), Feminism, bakhtin and the dialogic (pp. 25-38). Albany: State University of New York Press.

Koike, Y. (2011). Mori Tatsuya Kantoku Eiga 'A' 'A2' o Megutte. In I. Nobutaka \& RIRC (Eds.), Jōhō Jidai no Oumu Shinrikyō (pp. 340-345). Tokyo: Shunjusha.

Kōno, Y. (2001). Giwaku wa hareyoutomo: Matsumoto sarin jiken no hannin to sareta watashi. Tokyo: Bungei Shunjū.

Kōno, Y. (2008). Inochi Aru Kagiri: Matsumoto Sarin Jiken o Koete. Tokyo: Daisan Bunmeisha.

Kurasawa, F. (2009). A message in a bottle: bearing witness as a mode of transnational practice. Theory, Culture \& Society, 26(1), 92-111. doi:10.1177/0263276408099017. 
LaCapra, D. (2001). Writing history, writing trauma. Baltimore: Johns Hopkins University Press.

Lane, J. (2006). Bourdieu's politics: problems and possibilities. London: Routledge.

Mannheim, K. (1997). Ideology and Utopia. London: Routledge.

Morgan, M., \& Baert, P. (2015). Conflict in the academy: a study in the sociology of intellectuals. Basingstoke: Palgrave.

Mori, T. (dir.). (1998). A [film]. "A" Production Commitee.

Mori, T. (dir.). (2001). A2 [film]. "A” production committee.

Mori, T. (2002). A: Masukomi ga Hōdō Shinakatta Oumu no Sugata. Tokyo: Kadogawa Bunko.

Mori, T. (2012). A3. 2 vols. Tokyo: Shūeisha.

Mori, T., \& Yasuoka, T. (2001). A2. Gendai Shokan: Tokyo.

Mullins, M. R. (2012). The neo-nationalist response to the aum crisis: a return of civil religion and coercion in the public sphere? Japanese Journal of Religious Studies, 39(1), 99-125.

Murakami, H. (1997). Underground. Tokyo: Kōdansha.

Murakami, H. (1998). Underground 2: Yakusoku Sareta Basho de. Tokyo: Bungei Shunjū.

Murakami, H. (2003). Underground: the Tokyo gas attack and the Japanese psyche. London: Vintage.

Noda, N. (2010). Kakumei ka sensō ka: Oumu wa gurōbaru shihon shugi eno keishō datta. Tokyo: Saizō.

Oppenheimer, J. (dir.). (2012). The act of killing [film]. Final Cut for Real et al.

Oppenheimer, J. (dir.). (2014). The look of silence [film]. Final Cut for Real et al.

Ōta, T. (2011). Oumu Shinrikyō no Seishinshi: Roman Shugi, Zentai Shugi, Genri Shugi. Tokyo: Shunjūsha.

Reader, I. (2000a). Religious violence in contemporary Japan: the case of Aum Shinrikyō. Richmond: Curzon.

Reader, I. (2000b). Scholarship, Aum Shinrikyo, and academic integrity. Nova Religio, 3(2), 368-382.

Reader, I. (2001). Consensus shattered: Japanese paradigm shift and moral panic in the post-Aum era. Nova Religio, 4(2), 225-234. doi: 10.1525/nr.2001.4.2.225.

Said, E. W. (1994). Representations of the intellectual: the 1993 Reith lectures . New York: Pantheon Books.1st American ed

Said, E. W. (1995). The politics of dispossession: the struggle for Palestinian self-determination, 1969-1994. London: Vintage.

Sasa, A. (1995). Genkōhō no tekiyō wa 'hitsuyō aku.' Asahi Shimbun. 10 October: 4.

Sennett, R. (1998). The corrosion of character: the personal consequences of work in the new capitalism. London: Norton.

Sennett, R. (2012). Together: the rituals, pleasures and politics of Co-operation. London: Allen Lane.

Shils, E. (1958). The intellectuals and the powers: some perspectives for comparative analysis. Comparative Studies in Society and History, 1(1), 5-22.

Shimada, H. (2012). Oumu Shinrikyō Jiken I: Busōka to Kyōgi. Tokyo: Toransubyū.

Shimazono, S. (1995). In the wake of Aum: the formation and transformation of a universe of belief. Japanese Journal of Religious Studies, 22(3/4), 381-415.

Simko, C. (2012). Rhetorics of suffering: September 11 commemorations as theodicy. American Sociological Review, 77(6), 880-902. doi:10.1177/0003122412458785.

Smelser, N. J. (2004). Psychological trauma and cultural trauma. In Cultural trauma and collective identity, by J. C. Alexander, R. Eyerman, B. Giesen, N. J. Smelser, and P. Sztompka, (pp. 31-59). Berkeley, CA: University of California Press.

Swartz, D. (2013). Symbolic power, politics, and intellectuals: the political sociology of Pierre Bourdieu. Chicago: University of Chicago Press.

Takahashi, S. (2008). Koko ni Iru Koto: Chikatetsu Sarin Jiken no Izoku to Shite. Tokyo: Iwanami Shoten.

Thomas, J. B. (2012). Horrific 'cults' and comic religion manga after Aum. Japanese Journal of Religious Studies, 39(1), 127-151.

Tsuji, R. (2011). Oumu Shinrikyō to Inbō Ron. In I. Nobutaka \& RIRC (Eds.), Jōhō Jidai no Oumu Shinrikyō (pp. 360-384). Tokyo: Shunjūsha.

Tsukada, H. (2011). Shinritō No Undō Tenkai to Katsudō Naiyō. In I. Nobutaka \& RIRC (Eds.), Jōhō Jidai no Oumu Shinrikyō (pp. 307-327). Tokyo: Shunjūsha.

Umehara, T. (1995). Chitekina yajū umidasu gendai no higeki. Asahi Shimbun. 2 June: 4.

Ushiyama, R. (2014). Richard Dawkins as a public intellectual after The God Delusion: a British study. American Journal of Cultural Sociology, 2(3), 300-328. doi: 10.1057/ajcs.2014.7 .

Weber, M. (1993 [1922]). The sociology of religion. Boston: Beacon Press.

Yamauchi, M. (1995) Media jihyō: Oumu jiken no teguchi kaimeishi saihatsu bōshi. Yomiuri Shimbun. 21 May: 16.

Yomiuri Shimbun (1995a). Yamanashi no sanroku de sarin zanryūbutsu o kenshutsu. 1 January: 1.

Yomiuri Shimbun (1995b). Oumu Shinrikyō ga 'Shūkan Asahi' hōdō de baishō teiso. Yamanashi no sarin zanryūbutsu jiken. 10 January: 30 . 
Yomiuri Shimbun (1995c). Oumu Shinrikyō ga Shinchōsha nado uttae. Sarin no zanryūbusshitsu kenshutsu mondai de. 14 January: 30.

Yomiuri Shimbun (1995d). Yurushigatai chikatetsu sarin jiken. 21 March: 1.

Yomiuri Shimbun (1995e). (Shasetsu) Kyōshinteki na hankō o danjite yurusuna. 21 March: 3.

Yomiuri Shimbun (1995f). Jūsōbi, bōdoku masuku de totsunyū. 'Oumu Shinrikyō' sousaku 3.22 dokyumento. 22 March (Eve. Ed.): 2.

Yomiuri Shimbun (1995g). Sarin hōdō, kiroku nurikae zokuzoku. 30 March (Eve. Ed.) 8.

Yomiuri Shimbun (1995h). 'Kuni to Kuni no tatakai no kan' oumu sōsa de Nonaka Kokka Kōan Iinchō ga kyōchō. 25 April (Eve. Ed.): 2.

Yomiuri Shimbun (1995i). Oumu Asahara dokusai taisei. Guntai to sokkuri. Shukkesha o 14 kaikyū. Hitorā sonkei. 26 May: 19.

Yomiuri Shimbun (1995j). (Shasetsu) Oumu no Kiken na byōkon o issō seyo. 7 June: 3.

Yomiuri Shimbun (1995k). Doku demo karuto kyōdan ryūsei. Shūmatsuron ya 'reikan shōhō' mo. 3 July: 6.

Yomiuri Shimbun (1997a). Shūkan besuto serā. Tankōbon, bungei 1i wa 'Shitsurakuen'. 29 March (Eve. Ed.): 3.

Yomiuri Shimbun (1997b). 'Andāguraundo' Murakami Haruki cho. Monogatari no sekai ni gedokuzai o hanatsu. 23 March: 13.

Yomiuri Shimbun (1998). Shūkan besuto serā. Tankōbon, bungei 1i wa 'Tariki.' 5 December (Eve. Ed.): 6.

Yomiuri Shimbun (1999). 'Yakusoku sareta basho de' Murakami Haruki cho. Intabyū de ukabu setsujitsu na kotoba. 17 January: 9.

Yomiuri Shimbun (2000a). Chikatetsu sarin jiken '5 nen tattemo mune tsumaru.' 21 March: 38a.

Yomiuri Shimbun (2000b). Chikatetsu sarin jiken 'shazai to hoshō o jikkō'. Oumu ga komento. 20 March: 38b

Yomiuri Shimbun (2004). 'Chikatetsu sarin jiken' kara 9 nen. Ekiin ra mokutō. 'Fukaku aitō no nen.' Oumu ga danwa." 21 March: 38.

Yomiuri Shimbun (2010). Chikatetsu sarin jiken 15 nen. Izoku ni 'kugiri' nai. Shokkidana ima mo boufu no chawan. 20 March (Eve. Ed.): 1.

Yomiuri Shimbun (2015a). Kyōaku tero wasurenu chikatestu sarin 20 nen higaisha 'shimin hyouteki yurusanai.' 20 March (Eve. Ed.): 1.

Yomiuri Shimbun (2015b). 'Kienu kyōi' (4) Kokoro no kizu nao fukaku 'murikai' 'fūka' nayamu higaisha. 21 March: 39.

Yoshimi, S. (2009). Posuto Sengo Shakai. Tokyo: Iwanami Shoten.

Rin Ushiyama is a $\mathrm{PhD}$ candidate in Sociology at the University of Cambridge. His $\mathrm{PhD}$ dissertation investigates the collective memory of the Aum Affair, with a focus on the performative roles of various actors and institutions that have shaped and influenced public memories of Aum's crimes and terrorist attacks. He is also the author of "Richard Dawkins as a public intellectual after The God Delusion: a British study," published in the American Journal of Cultural Sociology (2014).

Patrick Baert is Professor of Social Theory at the University of Cambridge and a Fellow at Selwyn College, Cambridge. His current research interests are in social theory, the sociology of intellectuals, and intellectual history. Amongst his recent publications are The Existentialist Moment; The Rise of Sartre as a Public Intellectual (Baert 2015) and Conflict in the Academy; A Case-Study in the Sociology of Intellectuals (Morgan and Baert 2015). 